\title{
The Role of Agricultural Education in Ensuring National Security in Nigeria
}

\section{Francis, A. Angbre ${ }^{1}$}

Department of Agricultural Education, College of Education, Akwnaga, Nasarawa State

\begin{abstract}
Nigeria is presently facing serious security challenges and instability that threaten our existence as people of one destiny. This article examines the important roles agricultural education can play in ensuring our national security. Vocational agriculture is a skill acquisition training programme for youths to be self-employed and self-reliance in agricultural production for empowerment. In addition, democratic principles and the rule of law must be enshrined in our political life for equity, fairness and justice. The roles of agricultural education in ensuring national security are in the areas of reduction in rural-urban migration, youth empowerment and reduction in youth unemployment and growth in industry. In conjunction with this, government needs to take pro-active security measures for the security and safety of the nation.
\end{abstract}

Keywords: Role, Agricultural education, Ensuring, National security.

\section{Contents}

1. Introduction ..............................26

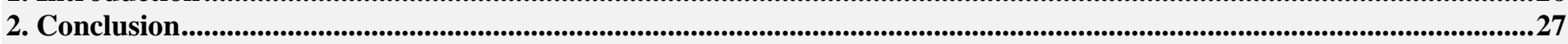

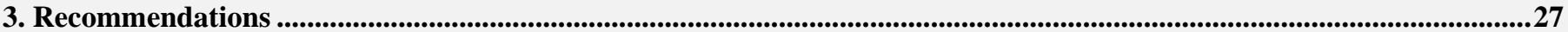

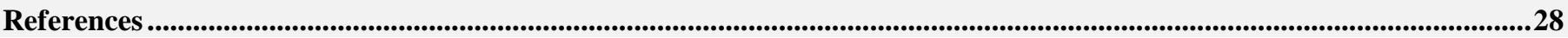

Citation | Francis, A. Angbre (2016). The Role of Agricultural Education in Ensuring National Security in Nigeria. Agriculture and Food Sciences Research, 3(1): 25-28

DOI:

$\operatorname{ISSN}(\mathbf{E})$ :

$\operatorname{ISSN}(\mathbf{P})$ :

Licensed:

Funding:

Competing Interests:

Transparency:

10.20448/journal.512/2016.3.1/512.1.25.28 Crossret

2411-6653

2411-6653

This work is licensed under a Creative Commons Attribution 3.0 License $($ (c) $)$ EY

This study received no specific financial support.

The author declares that there are no conflicts of interests regarding the publication of this paper.

The author confirms that the manuscript is an honest, accurate, and transparent account of the study was reported; that no vital features of the study have been omitted; and that any discrepancies from the study as planned have been explained.

History:

Ethical:

Received: 26 April 2016/ Revised: 18 May 2016/ Accepted: 21 May 2016/ Published: 26 May 2016

Publisher:

This study follows all ethical practices during writing.

Asian Online Journal Publishing Group 


\section{Introduction}

Nigeria is at present facing security challenges which threaten the corporate existence and stability of the country. This comes into force in the wake of the increasing terrorism, kidnapping armed robbery, cultism, political thugery, and above all, ethnic, Fulani herdsmen/farmers and religious clashes. The level of insecurity is on the increase despite the huge sums of money budgeted on yearly basis as security vote by the three tiers of government. Security is a collective responsibility of all citizens of a country in ensuring a secure and peaceful environment for optimal performance in chosen careers for the economic growth and development of this nation. A nation's stability is a sine-qua non for foreign investment as well as economic growth and development in all facets of our economy.

Adabara [1] affirmed that youth unemployment and poverty are on the increase in Nigeria, with an army of unemployed youths parading the streets in search of limited jobs. He further stressed that this has been responsible for the present security challenges the country is facing. It has also been opined that countries where government is a major employer of labour is bound to face high unemployment rate, Nigeria being a typical example [2]. Majority of the labour force in Nigeria are unskilled coupled with the mass rural-urban migration that tend to compound the unemployment situation and further aggravate security challenges.

The present 6-3-3-4 educational system is faulty because it has not been able to address the present youth unemployment, as most graduates are white collar job seekers instead of being job creators. This also points to the fact that the current school curriculum for agricultural education at NCE level is faulty and fails to address the present realities on the ground.

In the past, informed agricultural education where children were exposed to in their early life. They accompanied their parents to the farm, where they were taught the art and rudiments of farming with much emphasis on practical training in basic skills acquisition. This strong emphasis on practical has gradually given way to strong theoretical work in the modern formal agricultural education thereby creating challenges to agricultural education.

Development can only be achieved under a peaceful and stable environment which is a major pre-requisite for an increase in crop yield and sustained growth, especially in the efficient use of scarce resources for optimal production. Political instability, most especially in Africa, has been attributed to the undemocratic nature of our elections and complete absence of internal democracy within the political parties, thereby leading to discontentment among politicians [3]. This has plunged many African countries into instability that threatens national security with attendant destruction of lives and properties. In Nigeria where illiteracy level is high, there is the tendency of mutual suspicious of dominance which can culminate into security threat, thereby, jeopardizing security and national integration.

\subsection{Education for National Security}

Education is a long time investment by the three tiers of government and private individuals for its continued existence, preservation of culture and traditions, national integration and improvement of the society. Education is therefore, an instruction for national development and self-reliance. Suleiman [4] sees educationas a fulcrum of societal civilization and development. He further stressed that a civilized person relates and interacts with one another irrespective of ethnic, religious and cultural differences for national integration. At individual level, people need education for a variety of reasons: firstly, they need it for knowledge acquisition, this will enable them to understand the dynamics of the world and scientific innovations. Secondly, education is desired by many as a medium through which they can acquire professional and vocational skills to qualify for paid employment. Thirdly, education may also be desired for the social status it confers on its recipients. At the national level, education is required for development, integration and national security.

The products of our school system should be able to think for themselves, participate meaningfully in the act of decision making on important national issues and in passing mature judgment on all such matters that affect the security of the country. This is clearly what education attempts to build in the mind of Nigerian youths. This is most important and very necessary in a time when Nigeria is facing security challenges and instability, as well as the polarization of politics along ethnic and religion divides or issues.

The system of education should be able to produce citizens who are alive their social, political and economic responsibilities to their fatherland. Education should be geared toward imparting the basic principles of modern knowledge on its citizens. The products of the schools should be trained to acquire the ability to adopt such principles in solving their own problems and those of the society at large. Development which is an off shot of education can only be achieved under a peaceful and stable environment, when natural and manmade resources are effectively utilized in the production of goods and services that impact positively on the people.

The present 6-3-3-4 education curriculum at NCE level should be reviewed, so that it would be more practically oriented and be geared towards skill acquisition. This aspect of education is most crucial to the needs of our youths in this era of violence, militancy, terrorism, kidnapping, political thuggery, poverty and diseases. The only way out of this quagmire is to equip our youths with such skills that will help them to appreciate the opinion of others as people with right to life, as well as be able to cope with problems surrounding them.

Mohammed [5] sees vocational education as systematic learning experiences which are designed to fit individuals for gainful employment in recognized occupations as semi-skilled workers. Vocational education is therefore, that part of attitudes, work habit and application needed by workers to enter and make progress in employment on a useful productive basis. Vocational education is any form of education whose primary aim is to prepare persons for self employment in recognized occupation [6]. This implies that graduates from vocational education will be self-reliant and even become employer of labour (job creators) rather than job seekers.

Alabi [7] sees vocational agriculture as the training in broad fields of agriculture in order to provide knowledge and skills which will enable the individual make a living. Vocational education as a skill acquisition programme will therefore facilitate good quality education, improve health condition, empowerment, as well as prepare students against the hazards and hardship of the environment they might find themselves. It also contributes to the quality of life and the promotion of peaceful co-existence. Skills acquisition in vocational education is aimed at facilitating the 
development of psycho-social skills that the youths required to deal with the demands and challenges of everyday life as well as coping with emotions and stress [8].

Skills acquisition for self employment is the focus of vocational education. It is aimed at eradicating poverty and youth unemployment in the society. When the youths are gainfully employed and self reliant, they cannot be used or manipulated by greedy politicians to perpetuate violence in the society or be involved in acts of terrorism, kidnapping, armed robbery, ethnic and religious conflicts. Security challenges are the direct effect and consequences of a misplaced educational system and vocational programme.

A well articulated vocational education programme that is free from political gimmick and manipulated will go a long way in reducing security challenges and further rekindle the hope and aspiration of foreign and local investors.

Vocational education gives training and impacts the necessary skills to individuals who shall be self-reliant economically. Idleness is a base for laziness whose end result is involvement in criminal activities. A man who profitably engages in one productive exercise or the other is likely to be able to meet his basic needs as a responsible citizen [3].

\subsection{Role of Agricultural Education in National Security}

Agricultural education as a vocational course is an integral part of our educational system. Its main focus is on manpower training in skill acquisition in all the disciplines of agriculture. It is aimed at exposing, inculcating and developing knowledge, practical skills, competences and attitude. It provides the right type of skills and knowledge that will make an individual function effectively in any agricultural related job. Agricultural education roles in national security are as follows:

\section{- Reduction in Rural-Urban Migration}

One major cause of insecurity and instability in a nation is the mass movement of unemployed youths to the urban centres in search of jobs. They easily become available tools for use in promoting insecurity. If these youths are well trained in vocational agriculture, with basic skills acquisition in the various disciplines of agriculture and given the necessary assistance, they can be self-reliant. This will drastically reduce rural-urban migration, thereby creating an enabling environment for effective participation in nation building and development: therefore security is guarantee.

\section{- Youth Empowerment}

Poverty and hunger have been identified as major factors that make youths take to crime and other social vices. When youths are given the right manpower training in skills acquisition, especially in agriculture, they can become self-reliant in their fields of specialization. This will improve their economic power/income and be able to meet their nutritional requirement for healthy living and physical development. With improvement in economic power and social status as well as enough food on the youth's table, the rate of crime and involvement in violence will be a thing of the past.

\section{- Reduction in Youth Unemployment}

In Nigeria, agriculture is a major employer of labour when compared with other sectors of the economy. Training in vocational agriculture allows for skill acquisition in all the disciplines of agriculture which further makes the youths to be self-employed. When they are fully engaged in their chosen fields, they no longer have the time to be involved in violence and other criminal activities. This will reduce or eliminate insecurity in our society.

- Self Reliance in Food Production

When youths put into practical use the acquired skills in vocational agriculture, there would be abundance of food for the teaming population. The increase in food production would be sustained and the country can boast of self-reliance in agricultural production. Poverty and hunger would be eradicated from the society, thereby paving the way for peace and stability to prevail in the country.

\section{- Industrial Growth}

Availability of essential agricultural raw materials and its effective utilization can only be achieved when the right skills are acquired through training. The skilled manpower goes into mass production, which are essential pre-requisites for industrial growth. The multiplier effect of this is the creation of more job opportunities for the unemployed youths, reduction in poverty level and crime. The overall benefit of this to the society is the reduction in security threats.

\section{Conclusion}

Education is a veritable tool in the fight against security challenges in Nigeria. To effectively achieve these objectives, the educational system must be such that inculcates skills acquisition through effective training in vocational agriculture and entrepreneurship. This is to meet up with the challenging demands of our society, which has been characterized by different challenges like terrorism, violence, kidnapping, armed robbery, political thuggery, etc. Agricultural education as a vocational course can effectively play a major role in ensuring national security.

In addition to skills acquisition programme, government needs to take pro-active measures that would further enhance the security and safety of the people. This can be achieved through strict adherence to democratic principles and rule of law in our polity and proper screening of people at various government and private agencies.

\section{Recommendations}

The important roles agricultural education play in ensuring national security are very glaring and cannot be overlooked in the present dispensation. For vocational training in agriculture to succeed in combating the present security challenges, the following recommendations are proffered:

- The Government should as a matter of urgent importance put in place ways on how to create employment opportunities through agricultural educational by using the principles and practice of agriculture create wealth and jobs. 
- Curriculum in vocational agriculture at NCE level should be reviewed, so that it will be more practically oriented.

- Vocational education should be made compulsory at all levels of our tertiary institutions.

- Teachers need to be equipped with necessary skills that are most needed to inculcate such knowledge into our youths through short in-service training.

- Funds should be made available at the right time to make our schools functional and efficient in impacting knowledge and skills on the students.

- Government should urgently put in place policies that would fully engage every citizen in one form of economic activity or the other that would enable them to earn a living. This will go a long way in ensuring national security.

- There should be serious public awareness complain as to the importance of peaceful coexistence among the general public.

- Government also need to take proactive security measures for the security and safety of its citizens.

- Security is join responsibility of all citizens, therefore, everyone should join hands with the government to fight this security challenges.

- Security is a joint responsibility of all citizens. They should join hands with government to fight this security challenges.

\section{References}

[1] I. Adabara, "Vocational agricultural education production means for strengthening Nigerian economy," Oju Journal of Vocational and Technical Education, vol. 2, pp. 32 -37, 2013.

[2] P. M. Kolade, "Agricultural education as panacea for national security," Belt Journal of Education in Nigeria, vol. 3, pp. 40 - 45, 2012.

[3] D. J. Ishaya, "The role of vocational and technical education in national development. The challenges of the new Millennium," Oju Journal of Vocational and Technical Education, vol. 2, pp. 165- 170, 2014.

[4] A. D. Suleiman, "Role of vocational agriculture in equipping youths for self employment in Nigeria," Benue State University Journal of Education, vol. 7, pp. 53 - 60, 2013.

[5] M. Mohammed, Foundation of vocational education, 5th ed. Enugu: Cape Publishers, 2010.

[6] A. U. Jimoh, Principles and methods in vocational and technical education. Nsukka: University Trust Publishers, 2012.

[7] M. B. Alabi, "Vocational and technical education in Nigeria: Challenges and prospects," Nigerian Vocational Journal. University of Nigeria, Nsukka, vol. 5, pp. 35 -40, 2011.

[8] K. I. Audu, "Achieving security and stability in Nigeria through employment generation potentials in agricultural education," Belt Journal of Education in Nigeria, vol. 4, pp. 9-13, 2013. 